\title{
The Special Supplement of Centennial Foundation of Revista de Medicina of the Scientific Department of University of Sao Paulo School Medicine
}

This special issue was conceived and organized by the editorial board of Revista de Medicina from 2015 to 2016: Gustavo Rosa Gameiro, Robert Zawadzki Pfann, Camila de Oliveira Nuñes, Gabriel Berlingieri Polho, Camila Alves da Silva and Thiago Quadrante de Freitas.

\section{Dedication}

This special commemorative edition is dedicated to all those who contributed, in one way or another, to the continuation of this journal.

This academic production is also dedicated to the love of medicine, a feeling which is often printed on these pages.

\section{Acknowledgment}

I would like to thank to God for the gift of life.

To our families, for giving us love and the strength to move forward.

To the Board of Directors of the USP Faculty of Medicine, particularly to Professor José Otávio Costa Auler Jr for the crucial support, availability, trust and attention.

To the FMUSP International Office (CRInt) for all the support and readiness with a special gratitude to Talita de Almeida.

To the Full Professors of FMUSP, a source of pride for us.

To the foreign authors for accepting our invitation.

To the national authors for their excellent work.

To the FMUSP Scientific Department, which enables the continuity and maintenance of the Journal over the years.

To the Executive Secretary, Suely Campos Cardoso, who has been following our work for 18 years.

To the Fabiola Rizzo Sanchez Anjos, for helping us in the final review of these issues.

To the ever efficient Editorial Board of the Revista de Medicina.

To the ever attentive Collaborators.

To the Clinical Board of the FMUSP Clinical Hospital for the topic suggestions and support.

To the Emeritus Professors of FMUSP, who have dedicated and continue to dedicate their time to the teaching of medicine.

To the Historic Museum of FMUSP for bringing memories back.

To the Faculty of Medicine Foundation for the support.

To the University of São Paulo's Integrated Library System (SIBiUSP) for supporting our ideas.

To the FMUSP Central Library for being so attentive towards the Journal.

To the School of Continuing Education for helping develop the new logo.

To the Telemedicine Subject for believing our work.

To our Friends, our partners for all seasons.

To the President of the Republic of Brazil, Mr. Michel Miguel Elias Temer Lulia, for your consideration. 
To the State of São Paulo Governor, Doctor Geraldo Alckmin, for acknowledging our work.

To the magnificent Dean of the University of São Paulo, Professor Marco Antônio Zago.

To the Publishers of the Revista de Medicina for keeping it alive.

To the Members of the Advisory Council for their essential participation in this journey.

To the Readers for all the affection.

To Guto Lacaz, for the commemorative issue cover art.

To the Brazilian Association of Science Editors (ABEC) for the acknowledgment.

To those who made the FMUSP Editorial Center real.

To the Fisioterapia \& Pesquisa (Physical Therapy \& Research) journal, Revista de Terapia Ocupacional da Universidade de São Paulo (Occupational Therapy Journal of the University of Sao Paulo), Revista da Escola de Enfermagem da USP (Journal of the USP Nursing School) and Clinics, for the exchange of experiences.

To all those who contributed to this issue and perhaps were not mentioned, we sincerely thank you.

\section{RM Editorial Board}

\section{5}

Gustavo Rosa Gameiro (editor-in-chief), Gabriel Berlingieri Polho (executive editor), Camila Alves da Silva, Thiago Quadrante Freitas, João Diego Carmona, Klara Kapronezai Winstanley, Robert Zawadzki Pfann, Camila de Oliveira Nuñes, Pablo Rodrigo Andrade da Silva, Isadora Campos de Sousa Abreu, Sara Yumi Motoike, Ricardo de Oliveira Gabriel Souza, Leila Tiemi Okajima.

\section{6}

Robert Zawadzki Pfann (editor-in-chief), Camila de Olvieira Nuñes (executive editor), Pablo Rodrigo Andrade da Silva, João Gabriel Magalhães Dias, Gustavo Rosa Gameiro, Gabriel Berlingieri Polho, Camila Alves da Silva, Thiago Quadrante Freitas, Viktor Sinkunas, Kayo Augusto de Almeida Medeiros, Brendha Cação Coimbra, Guilherme Yuiti Sikusawa, Jhonny Everson Gonçalves, Victor Eidi Koike Sakaguchi, Thamara Rodrigues da Costa.

\section{Advisory Scientific Council}

\section{Coordinator: Luiz Fernando Ferraz da Silva}

Alexandre Fogaça Cristante, Alfredo Luiz Jacomo, Ana Maria de Ulhôa Escobar, Anna Sara Shafferman Levin, Antonio Carlos Seguro, Berenice Bilharinho de Mendonça, Bruno Zilberstein, Daniel Campi Araujo de Andrade, Edmund Chada Baracat, Ilka Regina Souza de Oliveira, José Eduardo Krieger, José Otávio Costa Auler Júnior, José Ricardo de Carvalho Mesquita Ayres, John J. Godleski, Marcos Naoyuki Samano, Marisa Dolhnikoff, Niels Olsen Saraiva Câmara, Orestes Vicente Forlenza, Paulo Hilário Nascimento Saldiva, Pedro Carlos Carricondo, Pieter S. Hiemstra, Richard Verrier, Roberto Zatz, Roger Chammas, Rogério de Souza, Rosa Maria Rodrigues Pereira, Sandra Elisabete Vieira, Sarita Verma, Thomas Ruder, Uennis Tannuri,Valeria Aoki.

We are absolutely thankful for everybody who have helped to review the articles during this century in order to sustain the scientific excellence of Revista de Medicina.

\section{List of Senior Editors}

Camila Alves da Silva, Gabriel Berlingieri Polho, Gustavo Rosa Gameiro e Thiago Quadrante de Freitas. 


\section{List of RM Editors from its Foundation: 1916}

Ernesto de Sousa Campos (President), Jayme Candelaria (Editor-in-Chief), Reviewers: Flaminio Fávero, A. de Almeida Junior; Redatores Geraes: Ibrahim C. Madeira e J. Cardoso.

\section{List of RM Editors from 1980 to 2016}

André Luis Montagnini; Roberto Hyun, Dae Shin, Gisela Tirrone, José Elias Gianini; André Ecahine Vallentsits Estenssoro; Julio Cesar Madi; Sylvia Massue Iriya; Michael Burihan Cahali; Richard Armelin Borger; Bernardo Pedreira Coelho, Fábio Sawada Shiba, Márcia Ozaki, Silvia Sclowitz Pereira do Vale; Sergio Pereira Gonçalves, Virgílio Tiezzi Neto; Adriano Tachibana, Roberto de Oliveira Rocha, Armando dos Santos Cunha, Carlos Wagner Neumann Siqueira; Clarissa Bueno, Elvio Ferreira Junior, Nélio Reis Ferreira, Rodrigo Casagrande Tango; Celso Abdon Lopes de Mello, Patricia Augusta Viana Chineli, Tarso Augusto Duenhas Accorsi; Marco Antonio P. de Freitas Filho, Murilo Gatass, Patricia Viana Chinelli, Patrícia Reis, Renata Monteiro, Ricardo Luis Brinconi Pulido, Tarso Augusto Duenhas Accorsi, Thiago de Oliveira Morinaga; Ali Mohmoud, André Paranzini Faria. Christian Valle Morinaga, Eduardo S. Portugal e Silva, Leonel Tadao Takaoka, Renata Monteiro de Almeida, Ricardo Luis Brinconi de Pulido, Rodrigo de Oliveira Antonio; Juliana Tiemi Hirayama, Marystella Tomoe Takahashi, Sang Ken Kim; André Luiz Simão e Daniela Lima de Jesus; Bruno Caldin da Silva; Elisa Maria de Mesquita; Clarissa Nóbrega Gambarra Nascimento; Alan Saito Ramalho; Samuel Lucas dos Santos; Matheus Rozalem Aranha; Gabriel Engel Becher; Talita Rodrigues de Oliveira; Elaine Imaeda de Moura; Aline Scalisse Silva; Camila Alves da Silva; Gustavo Rosa Gameiro; Robert Zawadzki Pfann.

\section{List of Honorary and Meritorious Members of Revista de Medicina}

José Otávio Costa Auler Jr

\section{List of FMUSP's Full Professors in 2016}

\section{Department of Cardiopulmonology}

Carlos Roberto Ribeiro Carvalho

Fábio Biscegli Jatene

José Antonio Franchini Ramires

José Eduardo Krieger

Paulo Manuel Pego Fernandes

Roberto Kalil Filho

\section{Department of Surgery}

Edivaldo Massazo Utiyama José Otávio Costa Auler Júnior Miguel Srougi

Nelson De Luccia

Pedro Puech Leão

Rolf Gemperli

William Carlos Nahas

\section{Department of Internal Medicine}

Ana Claudia Latronico Xavier

Berenice Bilharinho de Mendonça

Eloísa Silva Dutra de Oliveira Bonfá

Irene de Lourdes Noronha
Irineu Tadeu Velasco

Jorge Elias Kalil Filho

Luiz Fernando Onuchic

Milton de Arruda Martins

Paulo Andrade Lotufo

Roberto Zatz

Rosa Maria Rodrigues Pereira

Vanderson Geraldo Rocha

Wilson Jacob Filho

Department of Dermatology

Cyro Festa Neto

José Antonio Sanches Junior

Department of the Speech, Physical and Occupational Therapy

Clarice Tanaka

Claudia Regina Furquim de Andrade

Selma Lancman

Department of Legal Medicine, Medical Ethics and Social and Work Medicine

Daniel Romero Muñoz 
Eduardo Massad

Linamara Rizzo Battistella

Department of Gastroenterology

Flair José Carrilho

Ivan Cecconello

Luiz Augusto Carneiro D’Albuquerque

\section{Department of Preventive Medicine}

José Eluf Neto

José Ricardo de Carvalho Mesquita Ayres

Paulo Rossi Menezes

Department of Infectious and Parasitic Diseases

Aluisio Augusto Cotrim Segurado

\section{Department of Neurology}

Gerson Chadi

Manoel Jacobsen Teixeira

Ricardo Nitrini

Umbertina Conti Reed

Department of Obstetrics and Gynecology

Edmund Chada Baracat

Marcelo Zugaib

\section{Department of Ophthalmology and Otorhinolaringology}

Remo Susanna Junior

Ricardo Ferreira Bento
Department of Orthopaedics and Traumatology

Gilberto Luis Camanho

Olavo Pires de Camargo

Tarcísio Eloy Pessoa de Barros Filho

\section{Department of Pathology}

Alberto José da Silva Duarte

Mirian Nacagami Sotto

Paulo Hilário Nascimento Saldiva

Venâncio Avancini Ferreira Alves

Department of Pediatrics

Magda Maria Sales Carneiro Sampaio

Sandra Josefina Ferraz Ellero Grisi

Uenis Tannuri

Vicente Odone Filho

Werther Brunow de Carvalho

Department of Psychiatry

Euripedes Constantino Miguel Filho

Geraldo Busatto Filho

Valentim Gentil Filho

Wagner Farid Gattaz

Department of Radiology and Oncology

Carlos Alberto Buchpiguel

Giovanni Guido Cerri

Paulo Marcelo Gehm Hoff

Roger Chammas 